\title{
Treatment of bipolar disorder
}

\author{
John R Geddes\# ${ }^{\#}$ and David J Miklowitz ${ }^{\#}$ \\ Department of Psychiatry, University of Oxford, Oxford, UK (Prof J R Geddes MD, Prof D J \\ Miklowitz PhD); and Division of Child and Adolescent Psychiatry, University of California, Los \\ Angeles (UCLA) School of Medicine, Los Angeles, CA, USA (Prof D J Miklowitz PhD)
}

\# These authors contributed equally to this work.

\begin{abstract}
We review recent developments in the acute and long-term treatment of bipolar disorder and identify promising future routes to therapeutic innovation. Overall, advances in drug treatment remain quite modest. Antipsychotic drugs are effective in the acute treatment of mania; their efficacy in the treatment of depression is variable with the clearest evidence for quetiapine. Despite their widespread use, considerable uncertainty and controversy remains about the use of antidepressant drugs in the management of depressive episodes. Lithium has the strongest evidence for long-term relapse prevention; the evidence for anticonvulsants such as divalproex and lamotrigine is less robust and there is much uncertainty about the longer term benefits of antipsychotics. Substantial progress has been made in the development and assessment of adjunctive psychosocial interventions. Long-term maintenance and possibly acute stabilisation of depression can be enhanced by the combination of psychosocial treatments with drugs. The development of future treatments should consider both the neurobiological and psychosocial mechanisms underlying the disorder. We should continue to repurpose treatments and to recognise the role of serendipity. We should also investigate optimum combinations of pharmacological and psychotherapeutic treatments at different stages of the illness. Clarification of the mechanisms by which different treatments affect sleep and circadian rhythms and their relation with daily mood fluctuations is likely to help with the treatment selection for individual patients. To be economically viable, existing psychotherapy protocols need to be made briefer and more efficient for improved scalability and sustainability in widespread implementation.
\end{abstract}

\section{Introduction}

Bipolar disorders types I and II affect about $2 \%$ of the world's population, with subthreshold forms of the disorder affecting another $2 \% .{ }^{1-2}$ Even with treatment, about $37 \%$ of patients relapse into depression or mania within 1 year, and $60 \%$ within 2 years. ${ }^{3}$ In the STEP-BD cohort ( $\mathrm{n}=1469), 58 \%$ of patients with bipolar disorder types I and II achieved recovery, but $49 \%$ had recurrences in a 2-year interval; twice as many of these recurrences were of depressive polarity (marked by sad mood, loss of interests, or fatigue) rather than of manic polarity (marked by elevated mood, grandiosity, and decreased need of sleep) ${ }^{4}$ After initial onset, patients with bipolar disorder have residual depressive symptoms for about a third of the weeks of their lives. ${ }^{5}$ In 2009, the direct and indirect costs of bipolar disorder were estimated to be US $\$ 151$ billion. ${ }^{6}$ Patients also experience psychotic symptoms, impaired functioning, compromised quality of life, and stigma. ${ }^{7,8}$

Correspondence to: Prof John Geddes, Department of Psychiatry, University of Oxford, Warneford Hospital, Oxford OX3 7JX, UK.

Conflicts of interest We declare that we have no other conflicts of interest. 
Treatment of bipolar disorder conventionally focuses on acute stabilisation, in which the goal is to bring a patient with mania or depression to a symptomatic recovery with euthymic (stable) mood; and on maintenance, in which the goals are relapse prevention, reduction of subthreshold symptoms, and enhanced social and occupational functioning. Treat ment of both phases of the illness can be complex, because the same treatments that alleviate depression can cause mania, hypomania, or rapid cycling (defined as four or more episodes in 12 months), and the treatments that reduce mania might cause rebound depressive episodes.

We focus on contemporary issues in the acute and maintenance treatment of bipolar disorder. Developments in diagnosis and neurobiology are beyond the scope of this review and are mentioned only when they have direct implications for management. Despite a substantial expansion of research into bipolar disorder and potential treatments during the past 2 decades, true advances have been few. The development of effective treatments for bipolar disorder is hampered by our scarce knowledge of basic disease mechanisms and the consequent absence of validated pharmacological targets, and unconvincing animal or human experimental drug models (table 1 provides a summary of putative treatment targets). Most newly introduced treatments for bipolar disorder, whether pharmacological or psychological, have been based on an extension of use from another disorder-eg, antipsychotics in mania and antidepressants or cognitive-behavioural therapy for bipolar depression. However, lithium remains unique because its main therapeutic use is in bipolar disorder, and investigation of its mechanism of action has, and remains, crucially important in the identification of future targets.

\section{Treatment of mania}

The pioneering trials of lithium and chlorpromazine were done in the 1970s and were followed by a focus on antiepileptics (eg, valproate and carbamazepine) in the 1980s and 1990s. Few trials directly assessing the comparative efficacy of different second-generation antipsychotics exist, but a mixed treatments meta-analysis compared 13 agents studied in 68 randomised controlled trials (16 073 participants). ${ }^{9}$ This review found substantial and clinically important differences in terms of both efficacy and tolerability between agents. Antipsychotic drugs seem to be better than anticonvulsants and lithium in the treatment of manic episodes. Olanzapine, risperidone, and haloperidol seem to have the best profile of presently available agents (figure) ${ }^{9}$ Therefore, antipsychotic agents will often be the appropriate short-term clinical treatment, although a drug with better long-term evidence of efficacy such as lithium might be preferred when continued drug therapy is planned.

\section{Treatment of bipolar depression}

The treatment of bipolar depression is a major challenge, with few treatments of proven efficacy and, in particular, substantial controversy about the role of antidepressant drugs. Authors of guidelines and consensus statements on this topic often ponder why antidepressants are so commonly used despite the scarce evidence for efficacy. ${ }^{30-32}$ Until recently, after the work of Emil Kraepelin, bipolar depressive episodes were deemed phenomenologically and biologically similar to unipolar depressive episodes. Even as late as the 1990s, inclusion and exclusion criteria in clinical trials of antidepressants in patients with depressive disorder did not usually either select or stratify according to polarity. Earlier trials suggested that when given with antimanic treatment, selective serotonin reuptake inhibitor antidepressants were more effective and no more likely to induce mania than placebo, and were less likely to induce mania than tricyclic antidepressants. ${ }^{32}$ In 2007, a large trial found no benefit associated with the addition of paroxetine or bupropion to a 
mood stabiliser; 33 another reported that paroxetine was no better at achieving a durable recovery than placebo. ${ }^{34}$

A recent updated meta-analysis of antidepressants in bipolar depression reported a pooled effect no different from placebo (relative risk [RR] of response $1 \cdot 17,95 \%$ CI 0.82-1.57) with statistically significant heterogeneity. ${ }^{35}$ Meta-analyses in patients with bipolar disorder have grouped antidepressant drugs together as one class, despite the observed statistically significant heterogeneity and the evidence in patients with unipolar disorder that antidepressant agents vary to a clinically significant degree in both efficacy and tolerability. ${ }^{36}$ Therefore, to conclude that no antidepressant agent is effective in bipolar depression is probably premature, although the emerging evidence suggests that paroxetine is ineffective.

The antiepileptic drug lamotrigine was investigated in patients with bipolar depression after a clinical benefit was seen after treatment with the drug in patients with bipolar disorder. ${ }^{37}$ A meta-analysis of individual patient-level data from five trials of lamotrigine in bipolar depression reported a modest treatment effect; however, no one trial showed statistically significant benefits of treatment with lamotrigine in comparison with placebo. Thus, the place of lamotrigine in acute treatment remains uncertain. ${ }^{38}$

Atypical antipsychotics have been investigated in bipolar depression with variable results. ${ }^{39}$ Treatment with quetiapine leads to more symptomatic improvement in patients with bipolar depression than do placebo, paroxetine, and lithium. ${ }^{39}$ Some evidence exists of a reduced risk of recurrence in patients who respond to acute-phase treatment and continue quetiapine rather than switch to placebo; thus, continuation could be of benefit in patients who can tolerate the drug's adverse effects, including sedation and weight gain. ${ }^{40}$ The reasonably fast onset of action of quetiapine is clinically useful because it provides clinicians and patients with a treatment that can be initiated early in the course of a worsening depression in the same way that antipsychotics are used for emerging manic symptoms. Combined olanzapine and fluoxetine leads to more symptomatic improvement than does olanzapine or placebo alone, which could suggest that fluoxetine is an effective treatment of acute bipolar depression or that the combination of fluoxetine and olanzapine is synergistic. ${ }^{41}$

So far, the investigation of atypical antipsychotic drugs has been instructive for both clinical and methodological reasons. Quetiapine and olanzapine-fluoxetine combination have regulatory approval for bipolar depression in some countries and are included as first-line recommendations in recent guidelines. Emerging evidence suggests that lurasidone might also be efficacious, whereas aripiprazole does not seem to be so. ${ }^{39,42}$ The transdiagnostic benefits of a drug like quetiapine, which is antipsychotic, antimanic, and antidepressant in both unipolar and bipolar depression, emphasises the importance of the investigation of treatment effects across conventional diagnostic boundaries. ${ }^{9,40,43}$ However, this nonspecificity and scarcity of convincing evidence of long-term disease modification by known mechanisms suggests that the effects are mediated by short-term alleviation of symptoms. Nonetheless, because bipolar depression is very difficult to treat, this relief is often useful for patients and clinicians. Further, combinations of atypical antipsychotics with selective serotonin-reuptake inhibitors, or with agents that have medium-term to long-term effects on depression (eg, lamotrigine) are often used in clinical practice and warrant investigation in clinical trials.

Up to a third of patients with bipolar disorder do not respond to treatments in naturalistic studies, ${ }^{4,5,7}$ these figures probably underestimate the proportion of treatment-resistant patients with depression in clinical practice. Even patients who receive adequate pharmacotherapy have lengthy and debilitating periods of subthreshold depressive 
symptoms after major episodes. Longitudinal studies estimate that patients with bipolar disorder type I spend as many as 3 weeks depressed for every 1 week (hypo)manic; the ratio in bipolar disorder type II is 37:1.5,44 Subthreshold depressive symptoms are associated with social and occupational impairment, ${ }^{45}$ and increased psychosocial impairment is prospectively associated with earlier recurrences. ${ }^{46,47}$

Very little evidence exists of effective strategies for patients who do not respond to first-line treatments. A recent review of strategies reported just seven small trials; one each for ketamine, pramipexole, lamotrigine, and risperidone, and two each for modafinil and electroconvulsive therapy. ${ }^{48}$ Therefore, recommendations in clinical practice guidelines for treatment-resistant bipolar depression are still often based on extrapolation from the evidence on augmentation and switching strategies in unipolar major depression. This situation might lead to an underestimation of the attendant risks of treatment-emergent hypomania or mania in patients with bipolar disorder.

\section{Long-term maintenance treatment}

Lithium, introduced by John Cade in 1949, remains the best established long-term treatment for bipolar disorder. ${ }^{49}$ Although the metal has been in clinical use for more than 50 years, the most convincing evidence of long-term efficacy comes from randomised clinical trials in which lithium was included as an active comparator. ${ }^{50} \mathrm{~A}$ meta-analysis of five placebocontrolled lithium maintenance trials $(\mathrm{n}=770)$ showed that lithium reduces the risk of manic relapses by $38 \%$ (RR $0.62,95 \%$ CI $0.50-0.84)$ and depressive relapse by $28 \%(0 \cdot 72,0.40$ $0 \cdot 95) .{ }^{50}$ Lithium is the only known anti-suicidal treatment with randomised evidence of a reduction in the risk of suicide of more than 50\%. ${ }^{51}$ However, the benefits of lithium are restricted by adverse effects and a low therapeutic index. ${ }^{52}$ Although little evidence exists of a clinically substantial reduction in renal function in most patients, the risk of end-stage renal failure remains unclear. The risk of congenital malformations in the babies of mothers who have taken lithium during pregnancy is uncertain, but probably lower than previously thought. The balance of risks should be considered before lithium is withdrawn during pregnancy. In addition to known effects of lithium on the thyroid, the risk of hyperparathyroidism is increased and calcium concentrations should be checked before and during treatment. ${ }^{52}$

The limitations of lithium mean that alternatives are often needed for long-term treatment. A pooled analysis of two randomised lamotrigine versus placebo trials reported a $36 \%$ reduction for lamotrigine in the risk of relapse over 18 months. ${ }^{53}$ Despite the dramatic increase in the use of valproate in the past two decades, ${ }^{54}$ placebo-controlled evidence for valproate in long-term prevention remains scarce. ${ }^{55}$ Moreover, the BALANCE trial found that lithium was better than valproate in the prevention of mood episodes (RR $0.71,95 \%$ CI 0.51-1.00), but a combined analysis finds heterogeneity between studies. Combination treatment with lithium plus valproate is better than treatment with valproate monotherapy $(0 \cdot 59,0 \cdot 42-0 \cdot 83) .{ }^{56}$

Enrichment designs are standard in continuation trials sponsored by industry. Enrichment selects patients with known acute response to, or who can tolerate, the investigational agent. Patients are then randomly assigned to either continue the investigational agent during the active trial or switch to placebo or an active comparator. The enrichment design can answer questions about the continued benefits of the investigational medicine, but is not a fair test of the comparator agents that do not have the prerandomisation selection. For example, one trial protocol treated 2438 patients with quetiapine for 4-24 weeks; 1226 (50\%) who responded to treatment were randomly allocated to continue quetiapine or to switch to placebo or lithium $(0 \cdot 6-1 \cdot 2 \mathrm{mEq} / \mathrm{L}) .{ }^{40}$ Over 104 weeks, time-to-recurrence of any mood 
event was significantly longer for patients given quetiapine versus placebo and for patients given lithium versus placebo.

Because antipsychotics are the most potent treatments in acute mania, ${ }^{9}$ in many clinical situations, it will seem reasonable to continue them after remission from the acute episode. ${ }^{30}$ However, there are few long-term trials, most use enrichment designs, and none have the same degree of independent replication of efficacy as lithium. Thus, the role of antipsychotics as long-term mood stabilisers remains uncertain.

\section{Psychosocial treatments for bipolar disorder}

Treatment guidelines increasingly suggest that optimum management of bipolar disorder needs integration of pharmacotherapy with targeted psychotherapy. ${ }^{30,57} \mathrm{~A}$ recent randomised trial in Denmark has shown clinical benefits from this approach. ${ }^{58}$ Psychological approaches build on evidence that psychosocial stressors, including excessive family discord or distress, negative life events, or events that disrupt sleep and wake rhythms or accelerate goal attainment are associated with relapses and worsening symptomatic states (table 1). ${ }^{23}$ The main goals of adjunctive psychotherapy for bipolar disorder include the education of patients, and when possible, caregivers, about strategies for the management of stress, the identification and intervention of early signs of recurrence, and how to keep regular lifestyle (eg, sleep and exercise) habits (panel) ${ }^{59}$ Moreover, in view of the high rate of non-adherence to drug treatments (up to $60 \%$ after acute episodes ${ }^{27}$ ), psychosocial treatments emphasise consistency with pharmacotherapy.

Evidence-based models of psychotherapy (table 2) include cognitive-behavioural therapy, family-focused therapy, interpersonal and social rhythm therapy, group psychoeducation, and systematic care management. Although these models have common objectives, their methods, assumptions, and structure differ substantially. ${ }^{59,84}$

\section{Adjunctive psychotherapy in acute treatment}

Patients in acute manic episodes are not likely to respond well to intensive psychotherapy because of insufficient insight or rejection of help. ${ }^{85}$ Some trials have examined whether psychotherapy enhances remission from acute depression. ${ }^{86}$ The STEP-BD study compared up to 30 sessions of family-focused therapy, interpersonal and social rhythm therapy, or cognitive-behavioural therapy (ie, intensive treatment) with a brief psychoeducational therapy (three individual sessions) for 293 patients with acute depression who also received mood stabilisers. Over 1 year, patients in intensive therapy recovered more rapidly (hazard ratio [HR] 1.47, 95\% CI 1.08-2.0) and were more likely to be clinically well $(1.58,1 \cdot 17-$ 2.13 ) in any study month than those in brief treatment. ${ }^{61}$ Effects extended to relationship functioning and life satis faction. ${ }^{62}$ No differences emerged between the three intensive modalities in symptoms or psychosocial functioning over 1 year. Interestingly, patients with depression in STEP-BD who were treated with mood stabilisers and randomly assigned to adjunctive anti depressant treatment did not recover faster than patients who were assigned to adjunctive placebo treatment. ${ }^{33}$ Therefore, psychosocial treatment might be a more effective adjunct to mood stabilisers than antidepressants after a bipolar depressive episode.

\section{Adjunctive psychotherapy in long-term maintenance}

Most studies of psychotherapy for bipolar disorder are maintenance trials in which patients receive standard drugs and either an experimental psychosocial intervention or usual care (eg, brief treatment or a supportive treatment of equal frequency and duration; table 1). A meta-analysis of eight maintenance psycho therapy trials, which included family, individual, and group treatment trials, yielded effect sizes ranging from an odds ratio (OR) of 0.57 (95\% 
CI $0 \cdot 39-0 \cdot 82)$ for reductions in any type of mood relapse to $1 \cdot 2(0 \cdot 3-2 \cdot 1)$ for enhanced social functioning. ${ }^{87}$ A second meta-analysis of ten trials showed an overall RR of 0.74 $(0 \cdot 64-0 \cdot 85)$ for mood relapse. ${ }^{88}$

\section{Family-focused therapy}

Family-focused therapy is based on the frequently replicated association between criticism and hostility in caregivers (so-called expressed emotion) and an increased likelihood of relapse in mood disorders and schizophrenia. ${ }^{25}$ Family-focused therapy involves the patient and caregivers (parents or spouse) in up to 21 sessions of psychoeducation, communication skills training, and problem-solving skills training. ${ }^{89}$ Two randomised controlled trials including symptomatic patients with bipolar I and II found that, in the 1-2 years after a manic, mixed, or depressive episode, patients with bipolar disorder who received familyfocused therapy and pharma cotherapy had 30-35\% lower rates of relapse and rehospitalisation and less severe symptoms than did patients in case manage ment ${ }^{28}$ or equally intensive individual treatment. ${ }^{63}$ Two randomised controlled trials in paediatric populations - one in adolescents (aged 12-18 years) with bipolar disorder ${ }^{64}$ and one in children and adolescents (aged 9-17 years) with depression or hypomania with a first degree relative with bipolar disorder ${ }^{65}$ _ found that children and adolescents who received familyfocused therapy and pharmacotherapy recovered more rapidly from depressive episodes (HR $0 \cdot 37-0.54)$ than did children and adolescents in brief psychoeducation and pharmacotherapy.

The education of caregivers about bipolar disorder might translate into benefits for patients, even if patients do not attend educational sessions. In one randomised controlled trial, ${ }^{68}$ remitted patients whose relatives attended psychoeducation groups had longer intervals before manic and hypomanic episodes than did those whose relatives did not attend groups. In a second trial, ${ }^{66}$ patients whose caregivers attended 12-15 family education sessions showed significant decreases in symptoms of depression, especially if caregivers also showed mood improvement. Thus, adjunctive family interventions have the potential to lengthen periods of stability and alleviate residual symptoms in maintenance care. However, differences in treatment preferences, cultural factors (eg, willingness to disclose in front of others), and family structure (eg, parental vs spousal) might affect the willingness of patients or caregivers to participate in family-based treatment.

\section{Cognitive-behavioural therapy}

Cognitive-behavioural therapy presumes that recurrences of mood disorder are determined by pessimistic thinking in response to life events and core dysfunctional beliefs about the self, the world, and the future. ${ }^{90}$ Cognitive-behavioural therapy to treat depression has been adapted for patients with bipolar disorder with recognition that manic episodes are often associated with excessively optimistic thinking. ${ }^{71}$ One randomised controlled trial ${ }^{58}$ reported that patients who received 12-14 sessions of cognitive-behavioural therapy were less likely to have depressive episodes and had better social functioning than patients in routine care for 30 months. However, an effectiveness trial $(n=252)$ comparing cognitivebehavioural therapy with treatment as usual in five UK community care centres found no advantage for cognitive-behavioural therapy over 18 months, except among patients with fewer than 12 previous episodes. ${ }^{73}$

A Canadian trial compared six group psychoeducation sessions with 20 sessions of individual cognitive-behavioural therapy, both with pharmacotherapy, in 204 patients in full or partial remission. ${ }^{75}$ No differences were recorded over 72 weeks in symptom burden or recurrence. Group psychoeducation was estimated to cost US\$180 per patient, whereas cognitive-behavioural therapy was estimated to cost \$1200 per patient. In summary, the evidence for adjunctive cognitive-behavioural therapy for relapse prevention is inconclusive. 


\section{Interpersonal and social rhythm therapy}

Substantial evidence exists that mood instability in bipolar disorder is related to changes in circadian rhythms (table 1). ${ }^{20}$ The relation between sleep and mood disturbances seem to be bidirectional. Polymorphisms in CLOCK genes are related to circadian mood fluctuations and recurrences in bipolar disorder. ${ }^{91}$ In one promising animal model, ${ }^{92}$ mice with mutations in CLOCK genes behaved in ways that resembled manic behaviour in people (eg, increases in activity and decreased sleep); these behaviours were reversed upon treatment with lithium.

Interpersonal and social rhythm therapy, an adaptation of the interpersonal psychotherapy for depression, uses a problem-solving approach to interpersonal problems by encouraging patients to maintain and regulate daily routines and sleep and wake rhythms. ${ }^{21}$ In a large $(\mathrm{n}=175)$ randomised clinical trial, ${ }^{21}$ acutely manic, mixed, or depressed patients with bipolar I disorder were assigned to weekly interpersonal and social rhythm therapy or to equally intensive clinical management, both with pharmacotherapy. After acute stabilisation, random assignment was done again (interpersonal and social rhythm therapy $v s$ clinical management) and treatment continued for a 2-year maintenance phase. No differences in time-to-recovery between the groups during acute stabilisation were recorded. However, patients who received interpersonal and social rhythm therapy in the acute phase had longer times to recurrence and better vocational functioning in the maintenance phase than did patients who received clinical management during the acute phase. Moreover, the effects of interpersonal and social rhythm therapy in the delay of recurrences were most pronounced in patients who had been able to stabilise their daily or nightly routines during acute treatment. ${ }^{21}$ Thus, to help patients to stabilise their sleep and wake rhythms after an acute episode might have downstream effects on the prevention of future mood instability.

\section{Group psychoeducation}

In view of the many patients who could benefit from psychoeducation, group approaches following a predesigned curriculum have been proposed. The Barcelona approach ${ }^{78}$ emphasises awareness of illness, treatment adherence, early detection of recurrences, and sleep and wake regularity. In a trial of patients with bipolar disorder types I and II in the euthymic phase of illness, patients were randomly assigned to pharmacotherapy and 21 sessions of structured group psychoeducation or 21 sessions of an unstructured support group. After 5 years, patients who had received the structured groups had fewer relapses and were ill for less time than those who had been in the unstructured groups. ${ }^{29,78}$ Moreover, over 5 years, the reduction in days in hospital translated into a cost savings of approximately $€ 5000$ per patient in psychoeducation. ${ }^{93}$

\section{Functional remediation}

Functional remediation treatment emphasises patients' cognitive functioning through exercises for memory, attention, problem solving, reasoning, and organisation. In a ten-site randomised clinical trial in Spain, ${ }^{79} 268$ euthymic patients who had moderate to severe psychosocial impairment were assigned to 21 weekly group sessions of functional remediation, 21 sessions of standard group psychoeducation, or treatment as usual. Patients in functional remediation showed greater changes in occupational and social functioning than did those treated as usual, but differed only slightly from patients in the standard psychoeducation groups. No differential effects of functional remediation were recorded for neurocognitive or clinical change variables. 


\section{Systematic care management}

Two research groups have examined collaborative care programmes that combine protocoldriven pharmacotherapy, group psychoeducation, and intensive patient monitoring by a nurse care manager. Importantly, these studies were done in managed health-care cooperatives in the USA and included large patient samples with systematic follow-up. In trials at a group health cooperative $(\mathrm{n}=441)^{82}$ and in 11 Veterans Administration sites $(\mathrm{n}=306),{ }^{83}$ patients were randomly assigned to systematic care or usual care. Although neither study showed reductions in relapses, patients in systematic care had fewer weeks in manic episodes than did those in usual care. In the Veterans Administration study, patients in collaborative care also had improved social functioning and quality of life over 2 years. Cost-effectiveness analyses suggested that the care programmes saved money despite their greater intensity of follow-up. ${ }^{82,83}$

\section{Future directions}

Advances in the pharmacological treatment of bipolar disorder have come mainly from the repurposing of drugs used in other neuropsychiatric disorders, and do not target the mood instability that characterises the disorder. Dopamine antagonism seems to be a potential target for antimanic treatments, but the scarce convincing evidence that increasing serotonergic transmission improves symptoms in bipolar depression shows the need for development of bipolar-specific validated targets for novel treatments. Existing treatments (especially lithium) and the gradual emergence of insights into the neurobiology of the disorder provide potential targets (table 1). Opportunities should increase with the implementation of new methods such as the use of induced pluripotential stem cells to provide in-vitro models of neural systems, ${ }^{94}$ the identification of genetic and epigenetic factors, ${ }^{95,96}$ and the use of optogenetics to develop more precise animal models. ${ }^{97}$

Meanwhile, faced with the neurobiological complexity of the disorder, present approaches to drug discovery and repurposing will need to use existing targets in addition to any novel targets such as oxidative damage. ${ }^{17}$

Following up leads emerging from insights into the underlying neurobiology is already producing promising results. For example, after evidence of dysfunction in the N-methyl-Daspartate-receptor complex in the glutamatergic system in bipolar disorder, two crossover trials $^{12,13}$ found that infusion of the N-methyl-D-aspartate antagonist ketamine produced rapid alleviation of depressive symptoms in bipolar depression. These findings open a new approach to drug development and provide insights into the neurobiology of the disorder. The recent identification of the failed stroke treatment antioxidant ebselen as a potential lithium mimetic — obtained from screening of 450 compounds from the National Institutes of Health Clinical Collection-is an elegant and comprehensive approach using several targets, which now needs clinical evaluation. ${ }^{98}$

Acceleration of the development of novel treatments needs improved validation strategies for preclinical targets and the development of innovative biomarkers and intermediate outcomes for use in early-phase clinical trials. ${ }^{99}$ Validation strategies might include neuroimaging, cognitive or biochemical measures, and molecular genetic studies. Moreover, a more deeply characterised picture of the core clinical phenotype is urgently needed. The emerging picture of the course of bipolar disorder is one of chronic mood instability rather than discrete episodes of mania and depression. ${ }^{100,101}$ Early detection of treatment effects on short-term mood instability could provide the much needed intermediate outcomes for early-phase trials and experimental medicine.

For example, clarification of the mechanisms by which different mood stabilisers and atypical antipsychotics affect sleep and circadian rhythms and their relation with daily mood 
fluctuations is likely to help with the treatment selection for individual patients.

Conventional episode-based maintenance designs are likely to be inefficient, especially for early-phase therapeutic development.

Substantial progress has been made in the past decade in understanding of the role of psychotherapy in bipolar disorder. All existing forms of psychotherapy for bipolar disorder include psychoeducation, although which didactic ingredients lead to the most clinical change is not clear (panel). The next generation of psychotherapy studies will need to systematically assess mediators in the pathways from treatments to changes in illness course. The identification of mechanisms of change-eg, regulation of sleep and wake rhythms, reductions in family conflict, consistency of adherence to drugs, or the ability to intervene early with prodromal symptoms - might lead to the development of briefer treatments with more durable effects. ${ }^{102}$ The identification of mediators might be enhanced by controlled dis mantling designs that test the effects of psychotherapies with and without the components believed to induce change. Further identification of psychological processes underlying mood instability, such as the role of imagery in increasing anxiety and mood instability, might lead to more focused psychological interventions. ${ }^{103}$

Drug and psychotherapy trials have largely proceeded independently of one another. Specifically, drug studies have not examined the effects of psychotropic agents on psychosocial variables (eg, a patient's ability to regulate emotions in response to life events), nor have psychotherapy studies analysed changes in presumed biological mechanisms (eg, degree of amygdala activation in emotional challenge paradigms ${ }^{104}$ ). Pragmatic trials that examine the interactive effects of psychotropic drugs and psychotherapy in maintenance treatment would help to move the field forward. For example, a trial in which patients with bipolar disorder in the depressive phase of illness are initially treated with quetiapine or lithium or both, and then randomly assigned to continued pharmacotherapy with adjunctive psychotherapy versus adjunctive antidepressants, could help to define effective algorithms for bipolar depression.

As the genetic and phenotypic characteristics of children who are predisposed to adult bipolar disorder are identified, ${ }^{105}$ the focus of treatment research may change to early intervention. One small randomised trial found that family-focused therapy was more effective than usual care in the treatment of hypomanic and depressive symptoms in young people (aged 9-17 years) with a first-degree bipolar relative. ${ }^{65}$ Whether early pharma cological or psychosocial interventions for prodromal youth can help to delay or prevent the transition to bipolar disorder types I or II in adulthood will be crucial to investigate in this decade.

Innovations in service provision often focus on the early detection of manic and depressive symptoms. ${ }^{58,82,83}$ In our opinion, early detection combined with helpful self-management and targeted psychosocial and drug treatment promises substantial benefits. To be economically sustainable, psychosocial protocols need to be standardised for settings that serve large numbers of patients and have few resources for clinician training. The addition of web-based interactive protocols that track mood and sleep cycles and provide real-time information to providers, such as our OXTEXT programme based on mood monitoring, might enhance this effort. ${ }^{102,103}$

\section{Acknowledgments}

JRG receives research funding from UK Medical Research Council, the European Union, the National Institute of Health Research, and the Stanley Medical Research Institute. He was expert witness for Dr Reddys Laboratories (India) and is Chief Investigator on the CEQUEL trial to which GlaxoSmithKline have contributed and supplied investigational drugs and placebo. DJM receives research funding from the National Institute of Mental Health, the 
National Alliance for Research on Schizophrenia and Depression, Danny Alberts Foundation, Daniel and Diana Attias Family Foundation, Carl and Roberta Deutsch Foundation, and the Kayne Foundation.

\section{References}

1. Merikangas KR, Akiskal HS, Angst J, et al. Lifetime and 12-month prevalence of bipolar spectrum disorder in the National Comorbidity Survey replication. Arch Gen Psychiatry. 2007; 64:543-52. [PubMed: 17485606]

2. Merikangas KR, Jin R, He JP, et al. Prevalence and correlates of bipolar spectrum disorder in the world mental health survey initiative. Arch Gen Psychiatry. 2011; 68:241-51. [PubMed: 21383262]

3. Gitlin MJ, Swendsen J, Heller TL, Hammen C. Relapse and impairment in bipolar disorder. Am J Psychiatry. 1995; 152:1635-40. [PubMed: 7485627]

4. Perlis RH, Ostacher MJ, Patel JK, et al. Predictors of recurrence in bipolar disorder: primary outcomes from the Systematic Treatment Enhancement Program for Bipolar Disorder (STEP-BD). Am J Psychiatry. 2006; 163:217-24. [PubMed: 16449474]

5. Judd LL, Akiskal HS, Schettler PJ, et al. The long-term natural history of the weekly symptomatic status of bipolar I disorder. Arch Gen Psychiatry. 2002; 59:530-37. [PubMed: 12044195]

6. Dilsaver SC. An estimate of the minimum economic burden of bipolar I and II disorders in the United States: 2009. J Affect Disord. 2011; 129:79-83. [PubMed: 20888048]

7. Judd LL, Akiskal HS, Schettler PJ, et al. Psychosocial disability in the course of bipolar I and II disorders: a prospective, comparative, longitudinal study. Arch Gen Psychiatry. 2005; 62:1322-30. [PubMed: 16330720]

8. Michalak E, Livingston JD, Hole R, Suto M, Hale S, Haddock C. 'It's something that I manage but it is not who I am': reflections on internalized stigma in individuals with bipolar disorder. Chronic Illn. 2011; 7:209-24. [PubMed: 21357643]

9. Cipriani A, Barbui C, Salanti G, et al. Comparative efficacy and acceptability of antimanic drugs in acute mania: a multiple-treatments meta-analysis. Lancet. 2011; 378:1306-15. [PubMed: 21851976]

10. Cousins DA, Butts K, Young AH. The role of dopamine in bipolar disorder. Bipolar Disord. 2009; 11:787-806. [PubMed: 19922550]

11. Stockmeier CA. Involvement of serotonin in depression: evidence from postmortem and imaging studies of serotonin receptors and the serotonin transporter. J Psychiatr Res. 2003; 37:357-73. [PubMed: 12849929]

12. Diazgranados N, Ibrahim L, Brutsche NE, et al. A randomized add-on trial of an N-methyl-Daspartate antagonist in treatment-resistant bipolar depression. Arch Gen Psychiatry. 2010; 67:793802. [PubMed: 20679587]

13. Zarate CA Jr, Brutsche NE, Ibrahim L, et al. Replication of ketamine's antidepressant efficacy in bipolar depression: a randomized controlled add-on trial. Biol Psychiatry. 2012; 71:939-46. [PubMed: 22297150]

14. Li X, Frye MA, Shelton RC. Review of pharmacological treatment in mood disorders and future directions for drug development. Neuropsychopharmacol. 2012; 37:77-101.

15. Harwood AJ. Lithium and bipolar mood disorder: the inositol-depletion hypothesis revisited. Mol Psychiatry. 2005; 10:117-26. [PubMed: 15558078]

16. Agam G, Shamir A, Shaltiel G, Greenberg ML. Myo-inositol-1-phosphate (MIP) synthase: a possible new target for antibipolar drugs. Bipolar Disord. 2002; 4(suppl 1):15-20. [PubMed: 12479670]

17. Andreazza AC, Young LT. The neurobiology of bipolar disorder: identifying targets for specific agents and synergies for combination treatment. Int J Neuropsychopharmacol. 2013; 1:1-14.

18. Newberg AR, Catapano LA, Zarate CA, Manji HK. Neurobiology of bipolar disorder. Expert Rev Neurother. 2008; 8:93-110. [PubMed: 18088203]

19. Strakowski SM, Adler CM, Almeida J, et al. The functional neuroanatomy of bipolar disorder: a consensus model. Bipolar Disord. 2012; 14:313-25. [PubMed: 22631617]

20. Harvey AG. Sleep and circadian functioning: critical mechanisms in the mood disorders? Ann Rev Clin Psychol. 2011; 7:297-319. [PubMed: 21166537] 
21. Frank E, Kupfer DJ, Thase ME, et al. Two-year outcomes for interpersonal and social rhythm therapy in individuals with bipolar I disorder. Arch Gen Psychiatry. 2005; 62:996-1004. [PubMed: 16143731]

22. Malkoff-Schwartz S, Frank E, Anderson B, et al. Stressful life events and social rhythm disruption in the onset of manic and depressive bipolar episodes: a preliminary investigation. Arch Gen Psychiatry. 1998; 55:702-07. [PubMed: 9707380]

23. Miklowitz DJ, Johnson SL. Social and familial risk factors in bipolar disorder: basic processes and relevant interventions. Clin Psychol Sci Pract. 2009; 16:281-96.

24. Johnson SL, Cuellar A, Ruggero C, et al. Life events as predictors of mania and depression in bipolar I disorder. J Abnorm Psychol. 2008; 117:268-77. [PubMed: 18489203]

25. Hooley JM. Expressed emotion and relapse of psychopathology. Ann Rev Clin Psychol. 2007; 3:329-52. [PubMed: 17716059]

26. Simoneau TL, Miklowitz DJ, Richards JA, Saleem R, George EL. Bipolar disorder and family communication: effects of a psychoeducational treatment program. J Abnorm Psychol. 1999; 108:588-97. [PubMed: 10609423]

27. Strakowski SM, Keck PE, McElroy SL, et al. Twelve-month outcome after a first hospitalization for affective psychosis. Arch Gen Psychiatry. 1998; 55:49-55. [PubMed: 9435760]

28. Miklowitz DJ, George EL, Richards JA, Simoneau TL, Suddath RL. A randomized study of family-focused psychoeducation and pharmacotherapy in the outpatient management of bipolar disorder. Arch Gen Psychiatry. 2003; 60:904-12. [PubMed: 12963672]

29. Colom F, Vieta E, Martinez-Aran A, et al. A randomized trial on the efficacy of group psychoeducation in the prophylaxis of bipolar disorder: a five year follow-up. Br J Psychiatry. 2009; 194:260-65. [PubMed: 19252157]

30. Yatham LN, Kennedy SH, Parikh SV, et al. Canadian Network for Mood and Anxiety Treatments (CANMAT) and International Society for Bipolar Disorders (ISBD) collaborative update of CANMAT guidelines for the management of patients with bipolar disorder: update 2013. Bipolar Disord. 2013; 15:1-44. [PubMed: 23237061]

31. Gijsman HJ, Geddes JR, Rendell JM, Nolen WA, Goodwin GM. Antidepressants for bipolar depression: a systematic review of randomised controlled trials. Am J Psychiatry. 2004; 161:153747. [PubMed: 15337640]

32. Frye MA, Ha K, Kanba S, et al. International consensus group on depression prevention in bipolar disorder. J Clin Psychiatry. 2011; 72:1295-310. [PubMed: 22075097]

33. Sachs GS, Nierenberg AA, Calabrese JR, et al. Effectiveness of adjunctive antidepressant treatment for bipolar depression. N Engl J Med. 2007; 356:1711-22. [PubMed: 17392295]

34. McElroy SL, Weisler RH, Chang W, et al. A double-blind, placebo-controlled study of quetiapine and paroxetine as monotherapy in adults with bipolar depression (EMBOLDEN II). J Clin Psychiatry. 2010; 71:163-74. [PubMed: 20122366]

35. Sidor MM, MacQueen GM. An update on antidepressant use in bipolar depression. Curr Psychiatry Rep. 2012; 14:696-704. [PubMed: 23065437]

36. Cipriani A, Furukawa TA, Salanti G, et al. Comparative efficacy and acceptability of 12 newgeneration antidepressants: a multiple-treatments meta-analysis. Lancet. 2009; 373:746-58. [PubMed: 19185342]

37. Weisler RH, Calabrese JR, Bowden CL, Ascher JA, DeVeaugh-Geiss J, Evoniuk G. Discovery and development of lamotrigine for bipolar disorder: a story of serendipity, clinical observations, risk taking, and persistence. J Affect Disord. 2008; 108:1-9. [PubMed: 18001843]

38. Geddes JR, Calabrese JR, Goodwin GM. Lamotrigine for treatment of bipolar depression: an independent meta-analysis and meta-regression of individual patient data from five randomised trials. Br J Psychiatry. 2009; 194:4-9. [PubMed: 19118318]

39. De Fruyt J, Deschepper E, Audenaert K, et al. Second generation antipsychotics in the treatment of bipolar depression: a systematic review and meta-analysis. J Psychopharmacol. 2012; 26:603-17. [PubMed: 21940761]

40. Weisler RH, Nolen WA, Neijber A, Hellqvist A, Paulsson B. Continuation of quetiapine versus switching to placebo or lithium for maintenance treatment of bipolar I disorder (Trial 144: a randomized controlled study). J Clin Psychiatry. 2011; 72:1452-64. [PubMed: 22054050] 
41. Tohen M, Vieta E, Calabrese J, et al. Efficacy of olanzapine and olanzapine-fluoxetine combination in the treatment of bipolar I depression. Arch Gen Psychiatry. 2003; 60:1079-88. [PubMed: 14609883]

42. Loebel, A.; Cucchiaro, J.; Silva, R., et al. Lurasidone monotherapy for the treatment of bipolar I depression: results of a 6-week, double-blind, placebo-controlled study. American Psychiatric Association; Philadelphia, PA: 2012.

43. Weisler RH, Montgomery SA, Earley WR, Szamosi J, Lazarus A. Efficacy of extended release quetiapine fumarate monotherapy in patients with major depressive disorder: a pooled analysis of two 6-week, double-blind, placebo-controlled studies. Int Clin Psychopharmacol. 2012; 27:27-39. [PubMed: 22027845]

44. Judd LL, Akiskal HS, Schettler PJ, et al. A prospective investigation of the natural history of the long-term weekly symptomatic status of bipolar II disorder. Arch Gen Psychiatry. 2003; 60:26169. [PubMed: 12622659]

45. Altshuler LL, Post RM, Black DO, et al. Subsyndromal depressive symptoms are associated with functional impairment in patients with bipolar disorder: results of a large, multisite study. J Clin Psychiatry. 2006; 67:1551-60. [PubMed: 17107246]

46. Weinstock LM, Miller IW. Functional impairment as a predictor of short-term symptom course in bipolar I disorder. Bipolar Disord. 2008; 10:437-42. [PubMed: 18402632]

47. Weinstock LM, Miller IW. Psychosocial predictors of mood symptoms 1 year after acute phase treatment of bipolar I disorder. Comp Psychiatry. 2010; 51:497-503.

48. Sienaert P, Lambrichts L, Dols A, De FJ. Evidence-based treatment strategies for treatmentresistant bipolar depression: a systematic review. Bipolar Disord. 2013; 15:61-69. [PubMed: 23190379]

49. Cade JFJ. Lithium salts in the treatment of psychotic excitement. Med J Aust. 1949; 36:349-52. [PubMed: 18142718]

50. Geddes JR, Burgess S, Hawton K, Jamison K, Goodwin GM. Long-term lithium therapy for bipolar disorder: systematic review and meta-analysis of randomized controlled trials. Am J Psychiatry. 2004; 161:217-22. [PubMed: 14754766]

51. Cipriani A, Pretty H, Hawton K, Geddes JR. Lithium in the prevention of suicidal behaviour and all-cause mortality in patients with mood disorders: a systematic review of randomised trials. Am J Psychiatry. 2005; 162:1805-19. [PubMed: 16199826]

52. McKnight RF, Adida M, Budge K, Stockton S, Goodwin GM, Geddes JR. Lithium toxicity profile: a systematic review and meta-analysis. Lancet. 2012; 379:721-28. [PubMed: 22265699]

53. Goodwin GM, Bowden CL, Calabrese JR, et al. A pooled analysis of 2 placebo-controlled 18month trials of lamotrigine and lithium maintenance in bipolar I disorder. J Clin Psychiatry. 2004; 65:432-41. [PubMed: 15096085]

54. Hayes J, Prah P, Nazareth I, et al. Prescribing trends in bipolar disorder: cohort study in the United Kingdom THIN primary care database 1995-2009. PLoS One. 2011; 6:e28725. [PubMed: 22163329]

55. Macritchie KA, Geddes JR, Scott J, Haslam DR, Goodwin GM. Valproic acid, valproate and divalproex in the maintenance treatment of bipolar disorder. Cochrane Database Syst Rev. 2001; 3:CD003196. [PubMed: 11687047]

56. Geddes JR, Goodwin GM, Rendell J, et al. Lithium plus valproate combination therapy versus monotherapy for relapse prevention in bipolar I disorder (BALANCE): a randomised open-label trial. Lancet. 2010; 375:385-95. [PubMed: 20092882]

57. Goodwin GM, Consensus Group of the British Association for Psychopharmacology. Evidencebased guidelines for treating bipolar disorder: Revised second edition-recommendations from the British Association for Psychopharmacology. J Psychopharmacol. 2009; 23:346-88. [PubMed: 19329543]

58. Kessing LV, Hansen HV, Hvenegaard A, et al. Treatment in a specialised out-patient mood disorder clinic v. standard out-patient treatment in the early course of bipolar disorder: randomised clinical trial. Br J Psychiatr. 2013; 202:212-19.

59. Miklowitz DJ, Scott J. Psychosocial treatments for bipolar disorder: Cost-effectiveness, mediating mechanisms, and future directions. Bipolar Disord. 2009; 11:110-22. [PubMed: 19538690] 
60. Miklowitz DJ, Otto MW, Frank E, et al. Psychosocial treatments for bipolar depression: a 1-year randomized trial from the Systematic Treatment Enhancement Program. Arch Gen Psychiatry. 2007; 64:419-27. [PubMed: 17404119]

61. Miklowitz DJ, Otto MW, Frank E, et al. Intensive psychosocial intervention enhances functioning in patients with bipolar depression: results from a 9-month randomized controlled trial. Am J Psychiatry. 2007; 164:1-8. [PubMed: 17202533]

62. Clarkin JF, Carpenter D, Hull J, Wilner P, Glick I. Effects of psychoeducational intervention for married patients with bipolar disorder and their spouses. Psychiatr Serv. 1998; 49:531-33. [PubMed: 9550248]

63. Rea MM, Tompson MC, Miklowitz DJ, Goldstein MJ, Hwang S, Mintz J. Family-focused treatment versus individual treatment for bipolar disorder: results of a randomized clinical trial. J Consult Clin Psychol. 2003; 71:482-92. [PubMed: 12795572]

64. Miklowitz DJ, Axelson DA, Birmaher B, et al. Family-focused treatment for adolescents with bipolar disorder: results of a 2-year randomized trial. Arch Gen Psychiatry. 2008; 65:1053-61. [PubMed: 18762591]

65. Miklowitz DJ, Schneck CD, Singh MK, et al. Early intervention for symptomatic youth at risk for bipolar disorder: a randomized trial of family-focused therapy. J Am Acad Child Adol Psychiatry. 2013; 52:121-31.

66. Perlick D, Miklowitz DJ, Lopez N, et al. Family-focused treatment for caregivers of patients with bipolar disorder. Bipolar Disord. 2010; 12:627-37. [PubMed: 20868461]

67. Miller IW, Keitner GI, Ryan CE, Uebelacker LA, Johnson SL, Solomon DA. Family treatment for bipolar disorder: family impairment by treatment interactions. J Clin Psychiatry. 2008; 69:732-40. [PubMed: 18363424]

68. Reinares M, Colom F, Sánchez-Moreno J, et al. Impact of caregiver group psychoeducation on the course and outcome of bipolar patients in remission: a randomized controlled trial. Bipolar Disord. 2008; 10:511-19. [PubMed: 18452447]

69. Fristad MA, Verducci JS, Walters K, Young ME. Impact of multifamily psychoeducational psychotherapy in treating children aged 8 to 12 years with mood disorders. Arch Gen Psychiatry. 2009; 66:1013-21. [PubMed: 19736358]

70. Cochran SD. Preventing medical noncompliance in the outpatient treatment of bipolar affective disorders. J Cons Clin Psychol. 1984; 52:873-78.

71. Lam DH, Hayward P, Watkins ER, Wright K, Sham P. Relapse prevention in patients with bipolar disorder: cognitive therapy outcome after 2 years. Am J Psychiatry. 2005; 162:324-29. [PubMed: 15677598]

72. Ball JR, Mitchell PB, Corry JC, Skillecorn A, Smith M, Malhi GS. A randomized controlled trial of cognitive therapy for bipolar disorder: focus on long-term change. J Clin Psychiatry. 2006; 67:277-86. [PubMed: 16566624]

73. Scott J, Paykel E, Morriss R, et al. Cognitive behaviour therapy for severe and recurrent bipolar disorders: a randomised controlled trial. Br J Psychiatry. 2006; 188:313-20. [PubMed: 16582056]

74. Zaretsky A, Lancee W, Miller C, Harris A, Parikh SV. Is cognitive-behavioural therapy more effective than psychoeducation in bipolar disorder? Can J Psychiatry. 2008; 53:441-48. [PubMed: 18674402]

75. Parikh SV, Zaretsky A, Beaulieu S, et al. A randomized controlled trial of psychoeducation or cognitive-behavioral therapy in bipolar disorder: a Canadian Network for Mood and Anxiety treatments (CANMAT) study. J Clin Psychiatry. 2012; 73:803-10. [PubMed: 22795205]

76. Meyer TD, Hautzinger M. Cognitive behaviour therapy and supportive therapy for bipolar disorders: relapse rates for treatment period and 2-year follow-up. Psychol Med. 2012; 42:1429_ 39. [PubMed: 22099722]

77. Swartz HA, Frank E, Cheng Y. A randomized pilot study of psychotherapy and quetiapine for the acute treatment of bipolar II depression. Bipolar Disord. 2012; 14:211-16. [PubMed: 22420597]

78. Colom F, Vieta E, Martinez-Aran A, et al. A randomized trial on the efficacy of group psychoeducation in the prophylaxis of recurrences in bipolar patients whose disease is in remission. Arch Gen Psychiatry. 2003; 60:402-07. [PubMed: 12695318] 
79. Torrent C, del Mar Bonnin C, Martinez-Aran A, et al. Efficacy of functional remediation in bipolar disorder: a multicenter randomized controlled study. Am J Psychiatry. 2013 published online March 20. DOI:10.1176/appi.ajp.2012.12070971.

80. Weiss RD, Griffin ML, Kolodziej ME, et al. A randomized trial of integrated group therapy versus group drug counseling for patients with bipolar disorder and substance dependence. Am J Psychiatry. 2007; 164:100-07. [PubMed: 17202550]

81. Perry A, Tarrier N, Morriss R, McCarthy E, Limb K. Randomised controlled trial of efficacy of teaching patients with bipolar disorder to identify early symptoms of relapse and obtain treatment. BMJ. 1999; 318:149-53. [PubMed: 9888904]

82. Simon GE, Ludman EJ, Bauer MS, Unutzer J, Operskalski B. Long-term effectiveness and cost of a systematic care program for bipolar disorder. Arch Gen Psychiatry. 2006; 63:500-08. [PubMed: 16651507]

83. Bauer MS, McBride L, Williford WO, et al. Collaborative care for bipolar disorder: Part II. Impact on clinical outcome, function, and costs. Psychiatr Serv. 2006; 57:937-45. [PubMed: 16816277]

84. Miklowitz DJ, Goodwin GM, Bauer M, Geddes JR. Common and specific elements of psychosocial treatments for bipolar disorder: a survey of clinicians participating in randomized trials. J Psychiatr Pract. 2008; 14:77-85. [PubMed: 18360193]

85. Anderson IM, Haddad PM, Scott J. Bipolar disorder. BMJ. 2012; 345:e8508. [PubMed: 23271744]

86. Miklowitz DJ. Adjunctive psychotherapy for bipolar disorder: state of the evidence. Am J Psychiatry. 2008; 165:1408-19. [PubMed: 18794208]

87. Scott J, Colom FEV. A meta-analysis of relapse rates with adjunctive psychological therapies compared to usual psychiatric treatment for bipolar disorders. Int J Neuropsychopharmacol. 2007; 10:123-29. [PubMed: 16787554]

88. Lam DH, Burbeck R, Wright K, Pilling S. Psychological therapies in bipolar disorder: the effect of illness history on relapse prevention—a systematic review. Bipolar Disord. 2009; 11:474-82. [PubMed: 19624386]

89. Miklowitz, DJ. Bipolar disorder: a family-focused treatment approach. 2nd ed. Guilford Press; New York: 2008.

90. Beck, AT.; Rush, AJ.; Shaw, BF.; Emery, G. Cognitive therapy of depression. Guilford Press; New York: 1987.

91. Benedetti F, Serretti A, Colombo C, et al. Influence of CLOCK gene polymorphism on circadian mood fluctuation and illness recurrence in bipolar depression. Am J Med Gen B: Neuropsychiatr Gen. 2003; 123:23-26.

92. Roybal K, Theobold D, Graham A, et al. Mania-like behavior induced by disruption of CLOCK. Proc Natl Acad Sci USA. 2007; 104:6406-11. [PubMed: 17379666]

93. Scott J, Colom F, Popova E, et al. Long-term mental health resource utilization and cost of care following group psychoeducation or unstructured group support for bipolar disorders: a costbenefit analysis. J Clin Psychiatry. 2009; 70:378-86. [PubMed: 19284929]

94. Grskovic M, Javaherian A, Strulovici B, Daley GQ. Induced pluripotent stem cells_opportunities for disease modelling and drug discovery. Nat Rev Drug Discov. 2011; 10:915-29. [PubMed: 22076509]

95. Cross-Disorder Group of the Psychiatric Genomics Consortium. Identification of risk loci with shared effects on five major psychiatric disorders: a genome-wide analysis. Lancet. 2013 published online Feb 27. DOI:10.1016/S0140-6736(12)62129-1.

96. Arrowsmith CH, Bountra C, Fish PV, Lee K, Schapira M. Epigenetic protein families: a new frontier for drug discovery. Nat Rev Drug Discov. 2012; 11:384-400. [PubMed: 22498752]

97. Tye KM, Deisseroth K. Optogenetic investigation of neural circuits underlying brain disease in animal models. Nat Rev Neurosci. 2012; 13:251-66. [PubMed: 22430017]

98. Singh N, Halliday AC, Thomas JM, et al. A safe lithium mimetic for bipolar disorder. Nat Commun. 2013; 4:1332. [PubMed: 23299882]

99. Gelenberg AJ, Thase ME, Meyer RE, et al. The history and current state of antidepressant clinical trial design: a call to action for proof-of-concept studies. J Clin Psychiatry. 2008; 69:1513-28. [PubMed: 19192434] 
100. Bopp JM, Miklowitz DJ, Goodwin GM, Stevens W, Rendell JM, Geddes JR. The longitudinal course of bipolar disorder as revealed through weekly text-messaging. Bipolar Disord. 2010; 12:327-34. [PubMed: 20565440]

101. Miklowitz DJ, Price J, Holmes EA, et al. Facilitated integrated mood management (FIMM) for adults with bipolar disorder. Bipolar Disord. 2012; 14:185-97. [PubMed: 22420594]

102. Hollon SD, Muñoz RF, Barlow DH, et al. Psychosocial intervention development for the prevention and treatment of depression: Promoting innovation and increasing access. Biol Psychiatr. 2002; 52:610-30.

103. Holmes EA, Geddes JR, Colom F, Goodwin GM. Mental imagery as an emotional amplifier: Application to bipolar disorder. Behav Res Ther. 2008; 46:1251-58. [PubMed: 18990364]

104. Phillips ML, Kupfer MJ. Bipolar disorder diagnosis: challenges and future directions. Lancet. 2013; 381:1663-71. [PubMed: 23663952]

105. Birmaher B, Axelson D, Goldstein B, et al. Four-year longitudinal course of children and adolescents with bipolar spectrum disorders: the Course and Outcome of Bipolar Youth (COBY) study. Am J Psychiatry. 2009; 166:795-804. [PubMed: 19448190] 


\section{Panel}

\section{Common objectives of psychosocial interventions for bipolar disorder}

- Improve ability to identify and intervene early with warning signs of recurrences

- Increase acceptance of the illness

- Enhance adherence with drug regimens

- Enhance ability to cope with environmental stressors associated with symptoms

- Stabilise sleep and wake rhythms and other daily routines

- Re-engage with social, familial, and occupational roles

- Enhance family relationships and communication

- Reduce drug or alcohol misuse 


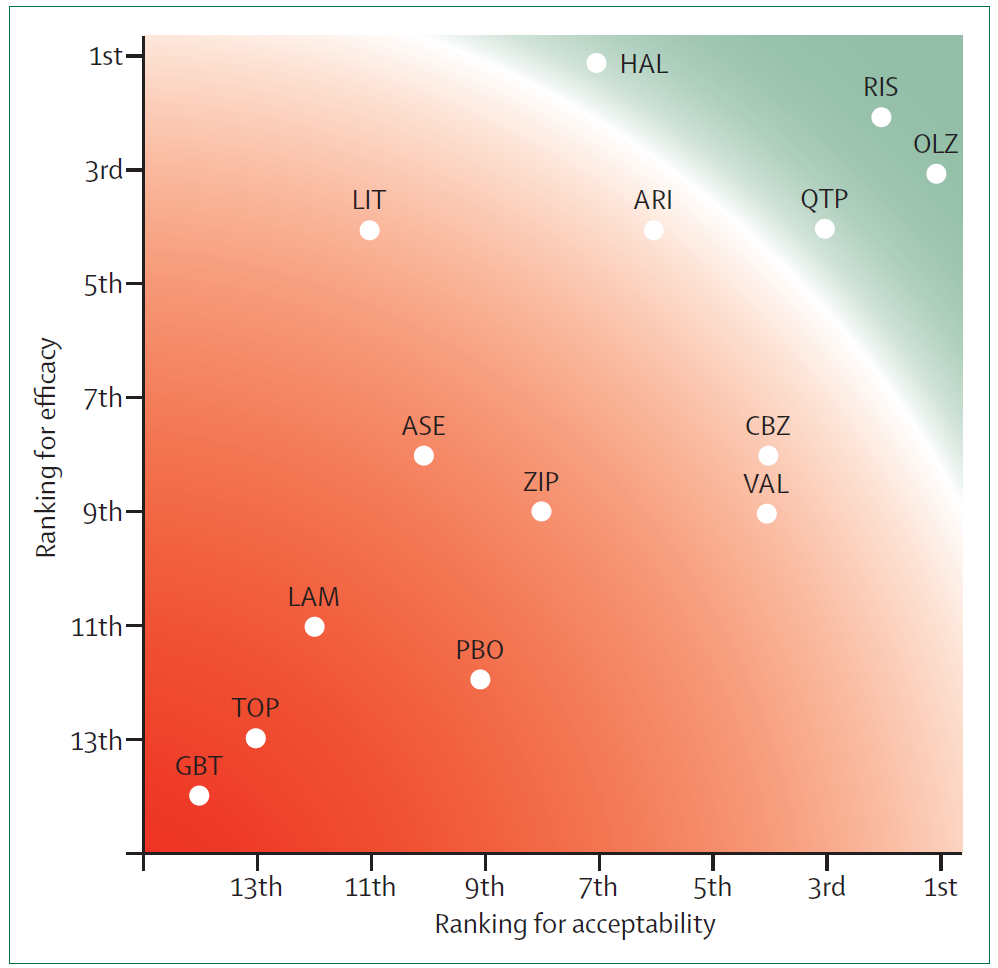

Figure. Ranking of antimanic drugs according to primary outcomes derived from multiple treatment meta-analysis

Efficacy is shown as a continuous outcome against the dropout rate. Treatments toward the red section combine the worst efficacy and tolerability profiles and treatments towards the green section combine the best profiles.

$\mathrm{ARI}=$ aripiprazole. $\mathrm{ASE}=$ asenapine. $\mathrm{CBZ}=$ carbamazepine. $\mathrm{VAL}=$ valproate.

GBT=gabapentin. HAL=haloperidol. LAM=lamotrigine. LIT=lithium. OLZ=olanzapine. $\mathrm{PBO}=$ placebo. $\mathrm{QTP}=$ quetiapine. $\mathrm{RIS}=$ risperidone. $\mathrm{TOP}=$ topiramate. $\mathrm{ZIP}=$ ziprasidone.

Reproduced from reference 10 . 
Table 1

Validation evidence of putative treatment development targets in bipolar disorder

Evidence of target validation

Neurotransmitter and neurohor
Dopamine ${ }^{9,10}$
Serotonin ${ }^{11}$
Glutamate ${ }^{12-14}$
Intracellular signalling
Inositol monophosphatase ${ }^{15,16}$
GSK-3 ${ }^{14,17}$
Protein kinase $\mathrm{C}$ pathway ${ }^{18}$
Calcium channels ${ }^{17}$

Neural mechanisms

Corticolimbic emotion control circuit ${ }^{19}$

\section{Sleep and circadian regulation}

Circadian clock associated with impaired sleep and weight changes ${ }^{20-22}$

\section{Psychosocial variables}

Responses to stressful events ${ }^{23,24}$

High expressed emotion and negative family interactions ${ }^{23,25,26}$

Drug adherence ${ }^{27-29}$
Antipsychotic agents block dopamine D2 receptors and are potent antimanics

Selective serotonin reuptake inhibitors of uncertain efficacy, atypical antipsychotics enhance serotonin activity

Valproate, lamotrigine, and some antidepressants modulate glutamate transmission; rapid alleviation of

depressive symptoms with ketamine infusion

Lithium, valproate, and carbamazepine reduce intracellular myoinositol concentration and increase neuronal growth cone spreading at therapeutic concentrations

Neuroprotective effects of lithium and other agents might be mediated by inhibition of GSK-3

Lithium and valproate inhibit PKC activity; tamoxifen inhibits PKC activity and might be antimanic

CACNA1C risk allele associated with bipolar disorder; lamotrigine inhibits voltage-activated calcium channels;

calcium channel blockers might be antimanic

Hyperactivation of amygdala and reduced anterior cingulate activity during mania; reduced ventrolateral

prefrontal cortex activity and hyperactivation of basal ganglia across mood states; reduced resting state

connectivity of amygdala and prefrontal regions

Antipsychotics, lithium, and valproate regulate sleep and circadian rhythms and stabilise mood; interpersonal and

social rhythm therapy is associated with delayed recurrences when social and circadian rhythms are regulated

Negative events are associated with depressive episodes; goal attainment events are associated with manic

episodes; psychosocial treatments can modulate responses to stress

Crucial attitudes in caregivers and negative verbal interactions between caregivers and patients associated with

greater likelihood of recurrence; family-focused therapy enhances family communication and is associated with

reduction in mood symptoms

Psychoeducational treatments improve adherence to mood stabilisers, leading to lower likelihood of manic recurrence 
Table 2

Randomised trials of adjunctive psychosocial intervention in bipolar disorder

Sample size

\section{STEP-BD}

Miklowitz et al, 293 adults $2007^{60,61}$

Family-focused approaches

\begin{tabular}{|c|c|c|c|}
\hline $\begin{array}{l}\text { Clarkin et al, } \\
1998^{62}\end{array}$ & 33 adults & $\begin{array}{l}25 \text { marital psychoeducation } \\
\text { sessions } \\
\text { over } 11 \text { months }\end{array}$ & Treatment as usual \\
\hline $\begin{array}{l}\text { Miklowitz et al, } \\
2003^{28}\end{array}$ & 101 adults & FFT (21 sessions) & $\begin{array}{l}\text { Crisis management } \\
\text { (2 sessions) }\end{array}$ \\
\hline Rea et al, $2003^{63}$ & 53 adults & FFT (21 sessions) & $\begin{array}{l}\text { Individual psychoeducatio } \\
(21 \text { sessions })\end{array}$ \\
\hline $\begin{array}{l}\text { Miklowitz et al, } \\
2008^{64}\end{array}$ & 58 adolescents & FFT (21 sessions) & $\begin{array}{l}\text { Brief psychoeducation } \\
\text { (3 sessions) }\end{array}$ \\
\hline $\begin{array}{l}\text { Miklowitz et al, } \\
2013^{65}\end{array}$ & $\begin{array}{l}40 \text { children and } \\
\text { adolescents }\end{array}$ & FFT (12 sessions) & $\begin{array}{l}\text { Brief psychoeducation } \\
\text { (1-2 sessions) }\end{array}$ \\
\hline $\begin{array}{l}\text { Perlick et al, } \\
2010^{66}\end{array}$ & $\begin{array}{l}46 \text { family } \\
\text { caregivers } \\
\text { of adult patients }\end{array}$ & $\begin{array}{l}\text { FFT-health promoting } \\
\text { intervention } \\
(12-15 \text { sessions })\end{array}$ & $\begin{array}{l}8-12 \text { health education } \\
\text { sessions }\end{array}$ \\
\hline
\end{tabular}

Multifamily groups

$\begin{array}{llll}\begin{array}{l}\text { Miller et al, } \\ 2008^{67}\end{array} & 92 \text { adults } & \begin{array}{l}\text { Single family treatment, } \\ \text { multifamily } \\ \text { group psychoeducation }\end{array} & \text { Treatment as usual } \\ & & & \\ \begin{array}{l}\text { Reinares et al, } \\ 2008^{68}\end{array} & 113 \text { adults } & \begin{array}{l}12 \text { weekly caregiver group } \\ \text { sessions over } \\ 3 \text { months }\end{array} & \text { Treatment as usual } \\ & & & \\ \begin{array}{l}\text { Fristad et al, } \\ 2009^{69}\end{array} & \begin{array}{l}165 \text { children } \\ \text { (ages } 8-11 \text { years })\end{array} & & \end{array}$

\section{CBT}

Cochran et al, $\quad 28$ adults

$1984^{70}$

Lam et al, $\quad 103$ adults

$2005^{71}$

Ball et al,

$2006^{72}$

52 adults
FFT, IPSRT, and CBT (up to 30 sessions)

Brief psychoeducation (3 sessions)
Control treatment

)




\begin{tabular}{|c|c|c|c|c|}
\hline & Sample size & Experimental treatment & Control treatment & Major outcomes \\
\hline $\begin{array}{l}\text { Scott et al, } \\
2006^{73}\end{array}$ & 253 adults & 22 sessions in 26 weeks & Treatment as usual & $\begin{array}{l}\text { No differences in time-to- } \\
\text { recurrence over } 18 \text { months; } \\
\text { subgroup of patients with < } 12 \\
\text { episodes had longer } \\
\text { time-to-recurrence in CBT }\end{array}$ \\
\hline $\begin{array}{l}\text { Zaretsky et al, } \\
2008^{74}\end{array}$ & 79 adults & 20 weekly sessions & $\begin{array}{l}\text { Individual psychoeducation } \\
\text { ( } 7 \text { sessions) }\end{array}$ & $\begin{array}{l}\text { No group differences in relapse } \\
\text { rates over } 1 \text { year; } 50 \% \text { fewer } \\
\text { days of depressed mood in CBT }\end{array}$ \\
\hline $\begin{array}{l}\text { Parikh et al, } \\
2012^{75}\end{array}$ & 204 adults & 20 weeks of individual CBT & $\begin{array}{l}6 \text { sessions of group } \\
\text { psychoeducation }\end{array}$ & $\begin{array}{l}\text { No differences in relapses or } \\
\text { symptom severity over } \\
18 \text { months }\end{array}$ \\
\hline $\begin{array}{l}\text { Meyer \& } \\
\text { Hautzinger, } \\
2012^{76}\end{array}$ & 76 adults & $\begin{array}{l}20 \text { sessions over } 9 \text { months of } \\
\text { CBT }\end{array}$ & $\begin{array}{l}20 \text { sessions over } 9 \text { months of } \\
\text { supportive treatment }\end{array}$ & $\begin{array}{l}\text { No differences in relapse rates } \\
\text { over } 33 \text { months }\end{array}$ \\
\hline \multicolumn{5}{|l|}{ IPSRT } \\
\hline $\begin{array}{l}\text { Frank et al, } \\
2008^{21}\end{array}$ & 175 adults & $\begin{array}{l}\text { Weekly sessions during acute } \\
\text { treatment } \\
\text { until recovered, monthly during } \\
\text { maintenance treatment }\end{array}$ & $\begin{array}{l}\text { Active clinical management } \\
\text { (same frequency) }\end{array}$ & $\begin{array}{l}\text { IPSRT during acute phase } \\
\text { associated with longer time to } \\
\text { recurrence during maintenance } \\
\text { phase }\end{array}$ \\
\hline $\begin{array}{l}\text { Swartz et al, } \\
2012^{77}\end{array}$ & $\begin{array}{l}25 \text { adults with } \\
\text { bipolar II } \\
\text { depression }\end{array}$ & $\begin{array}{l}\text { Weekly sessions for } 12 \text { weeks } \\
\text { (no drugs) }\end{array}$ & $\begin{array}{l}\text { Quetiapine monotherapy } \\
25-300 \mathrm{mg}\end{array}$ & $\begin{array}{l}\text { No differences in depression } \\
\text { response rates over } 12 \text { weeks }\end{array}$ \\
\hline \multicolumn{5}{|c|}{ Group psychoeducation } \\
\hline $\begin{array}{l}\text { Colom et al, } \\
2003,2009^{29,78}\end{array}$ & 120 adults & $\begin{array}{l}21 \text { weekly structured group } \\
\text { psychoeducation sessions }\end{array}$ & $\begin{array}{l}21 \text { weekly unstructured group } \\
\text { sessions }\end{array}$ & $\begin{array}{l}\text { Lower recurrence rates in } \\
\text { structured groups over } 5 \text { years }\end{array}$ \\
\hline $\begin{array}{l}\text { Torrent et al, } \\
2013^{79}\end{array}$ & 239 adults & $\begin{array}{l}21 \text { weekly sessions of } \\
\text { functional } \\
\text { remediation }\end{array}$ & $\begin{array}{l}21 \text { group psychoeducation } \\
\text { sessions or treatment as usual }\end{array}$ & $\begin{array}{l}\text { Functional remediation } \\
\text { associated with improved } \\
\text { functional outcomes compared to } \\
\text { usual treatment }\end{array}$ \\
\hline $\begin{array}{l}\text { Weiss et al, } \\
2007^{80}\end{array}$ & $\begin{array}{l}62 \text { adults with } \\
\text { comorbid } \\
\text { substance misuse }\end{array}$ & $\begin{array}{l}20 \text { weekly sessions of } \\
\text { integrated } \\
\text { cognitive behavioural groups }\end{array}$ & Drug counselling groups & $\begin{array}{l}\text { Fewer days per month of alcohol } \\
\text { use but more severe } \\
\text { mood symptoms in integrated } \\
\text { groups }\end{array}$ \\
\hline \multicolumn{5}{|c|}{ Individual psychoeducation } \\
\hline $\begin{array}{l}\text { Perry et al, } \\
1999^{81}\end{array}$ & 69 adults & $\begin{array}{l}\text { Seven to } 12 \text { sessions of } \\
\text { individual } \\
\text { psychoeducation }\end{array}$ & Routine care & $\begin{array}{l}\text { Increased time-to-manic- } \\
\text { recurrence and improved social- } \\
\text { occupational functioning in } \\
\text { individual psychoeducation }\end{array}$ \\
\hline \multicolumn{5}{|c|}{ Systematic care management } \\
\hline $\begin{array}{l}\text { Simon et al, } \\
2006^{82}\end{array}$ & 441 adults & $\begin{array}{l}2 \text { year multicomponent } \\
\text { intervention }\end{array}$ & Care as usual & $\begin{array}{l}\text { Decreased severity and duration } \\
\text { of manic episodes }\end{array}$ \\
\hline $\begin{array}{l}\text { Bauer et al, } \\
2006^{83}\end{array}$ & 306 adults & $\begin{array}{l}3 \text { year multicomponent } \\
\text { intervention }\end{array}$ & Care as usual & $\begin{array}{l}\text { Decreased duration of manic } \\
\text { episodes, better social } \\
\text { functioning and quality of life }\end{array}$ \\
\hline
\end{tabular}

FFT=family-focused treatment. CBT=cognitive-behavioural therapy. IPSRT=interpersonal and social rhythm therapy. 